\title{
Classifications in Brief: Rockwood Classification of Acromioclavicular Joint Separations
}

\author{
Jacob D. Gorbaty MD, Jason E. Hsu MD, Albert O. Gee MD
}

Received: 21 March 2016/Accepted: 8 September 2016/Published online: 16 September 2016

(C) The Association of Bone and Joint Surgeons \& 2016

\section{History}

Acromioclavicular (AC) joint separation is a common shoulder injury, representing up to $9 \%$ of all shoulder injuries $[8,19]$. The majority of AC injuries (44\%) occur in people in their twenties and are five times more common in men than in women [19]. They are especially numerous in younger patients participating in contact sports and represent $15 \%$, $20 \%$, and $41 \%$ of shoulder injuries in hockey, skiing, and American football, respectively [10, 15, 20, 27]. The most common mechanism of injury is by direct contact applied directly over the superolateral border of the shoulder while the humerus is in the adducted position.

In 1984, Rockwood first described his six-part classification system for AC joint separations [28]. He believed that previous classification systems by Cadenat [6] and Tossy et al. [32] did not adequately categorize all the distinct patterns of injury. Cadenat [6] classified AC

Each author certifies that he, or a member of his immediate family, has no funding or commercial associations (eg, consultancies, stock ownership, equity interest, patent/licensing arrangements, etc) that might pose a conflict of interest in connection with the submitted article.

All ICMJE Conflict of Interest Forms for authors and Clinical Orthopaedics and Related Research ${ }^{\circledR}$ editors and board members are on file with the publication and can be viewed on request.

\section{J. D. Gorbaty}

Department of Orthopaedic Surgery, Carolinas Healthcare System, Charlotte, NC, USA

J. E. Hsu, A. O. Gee ( $\square)$

Department of Orthopaedics and Sports Medicine, University of Washington, Seattle, WA 98195, USA

e-mail: ag112@uw.edu separations as either incomplete or complete, in which the joint capsule and the coracoclavicular (CC) ligaments are disrupted. He characterized a sequential process of acute AC injury, beginning with trauma to the AC ligaments, continuing to the $\mathrm{CC}$ ligaments, and finally disrupting the deltotrapezial fascia. Tossy et al. [32] characterized Type I injuries by sprained but still intact $\mathrm{AC}$ and $\mathrm{CC}$ ligaments; Type II by torn AC ligaments and partially torn CC ligaments; and Type III injuries by complete dislocations with complete disruption of the $\mathrm{AC}$ and the $\mathrm{CC}$ ligaments resulting in vertical instability of the AC joint. Allman [1] described a similar classification system as Tossy et al. but described the CC ligament in Type II injuries as being sprained without being torn.

Rockwood concurred with previous authors $[1,6,32]$ that a classification system for AC joint separations should be based on the severity of injury sustained by the capsular and extracapsular ligaments and supporting musculature. He suggested, however, that Type III AC separation as described by Tossy et al. was too broad and did not account for consistently distinct injury patterns with unique mechanisms of injury, radiographic appearance, soft tissue disturbances, and treatment [28].

\section{Purpose}

An ideal classification system groups similar diagnoses, provides prognostic information, and guides treatment options with a high degree of reproducibility. Toward this end, Rockwood sought to provide a better framework to explain the pathoanatomy, mechanism of injury, and anatomic severity of AC joint separations. His analysis was based on careful evaluation of radiographs and surgical findings from patients with $\mathrm{AC}$ separations he treated 
Table 1. Rockwood classification of acromioclavicular separations Types I-III

\begin{tabular}{|c|c|c|c|}
\hline Structure & I & II & III \\
\hline Acromioclavicular ligament & Sprained & Complete tear & Complete tear* \\
\hline Acromioclavicular Joint & Intact & $\begin{array}{l}\text { Disrupted; widened in the transverse } \\
\text { plane }\end{array}$ & $\begin{array}{l}\text { Dislocated; clavicle displaced superiorly relative to the } \\
\text { acromion }\end{array}$ \\
\hline Coracoclavicular ligaments & Intact & Sprained; slight widening of interval & Disrupted; interval widened up to $100 \%^{*}$ \\
\hline $\begin{array}{l}\text { Deltoid and trapezius } \\
\text { muscles }\end{array}$ & Intact & Possible partial detachment & High probability of detachment from distal clavicle \\
\hline
\end{tabular}

Table 2. Rockwood classification of acromioclavicular separations Types IV-VI

\begin{tabular}{|c|c|c|c|}
\hline Structure & IV & V & VI \\
\hline $\begin{array}{l}\text { Acromioclavicular } \\
\text { ligaments }\end{array}$ & Complete disruption & Complete disruption & Complete disruption \\
\hline $\begin{array}{l}\text { Acromioclavicular } \\
\text { joint }\end{array}$ & $\begin{array}{l}\text { Dislocated; clavicle displaced posteriorly } \\
\text { into or through the trapezius muscle }\end{array}$ & $\begin{array}{l}\text { Dislocated; extreme vertical incongruity } \\
\text { between lateral clavicle and acromion. }\end{array}$ & $\begin{array}{l}\text { Dislocated; clavicle displaced } \\
\text { inferior relative to the } \\
\text { acromion* }\end{array}$ \\
\hline $\begin{array}{l}\text { Coracoclavicular } \\
\text { ligaments }\end{array}$ & $\begin{array}{l}\text { Partial or complete disruption with change } \\
\text { in interval orientation }\end{array}$ & $\begin{array}{l}\text { Complete disruption; interval widened } \\
100 \% \text { to } 300 \%\end{array}$ & $\begin{array}{l}\text { Intact; interval is decreased or } \\
\text { reversed* }\end{array}$ \\
\hline $\begin{array}{c}\text { Deltoid and } \\
\text { trapezius } \\
\text { muscles }\end{array}$ & $\begin{array}{l}\text { High probability of detachment from } \\
\text { distal clavicle }\end{array}$ & $\begin{array}{l}\text { High probability of detachment from distal } \\
\text { clavicle }\end{array}$ & $\begin{array}{l}\text { Intact, partial, or complete } \\
\text { detachment }\end{array}$ \\
\hline
\end{tabular}

*In a continuation of Type VI, the clavicle is displaced inferior to the coracoid process. In this case the coracoclavicular ligaments are completely torn, and the coracoclavicular interval no longer anatomically exists.

between 1974 and 1984. He added categories to include the direction and distance of clavicle displacement and the degree of soft tissue involvement (integrity of the $\mathrm{AC}$ ligaments, CC ligaments, anterior deltoid, and trapezius).

\section{Description of the Rockwood Classification}

Rockwood described Type I through Type III separations as a sequential displacement of the AC joint and subsequent detachment of the AC ligament and CC ligaments (Table 1). In his expanded classifications, Type IV through Type VI, he included the direction of the displaced clavicle with relation to the acromion (Table 2). Integrity of the deltotrapezial fascia is affected in more severe patterns of injury (Fig. 1).

\section{Validation}

\section{Radiographs}

Rockwood's original classification was based on findings observed on plain radiographs, and studies have shown fair reliability in classifying injury and in its use for surgical decision making. Kraeutler et al. [16], using AP and axial radiographs of 28 patients with diagnoses of Type III, IV, or V AC joint separations, tested the inter- and intraobserver reliability by eight shoulder surgeons who classified each injury according to the Rockwood classification and stated whether they recommended operative or nonoperative treatment for each patient. Interobserver reliability was moderate among surgeons for classification (intraclass correlation coefficient [ICC], 0.602) and decision to operate (ICC, 0.469). Using Spearman's rank correlation coefficient $(\rho)$, intraobserver reliability among these surgeons was found to be moderate $(\rho=0.694)$. The kappa statistic ( $\kappa)$ was used to determine intraobserver reliability for the decision to operate based on a two-by-two contingency table comparing initial clinical decisions with a later decision with use of radiographs alone. The researchers found only slight agreement $(\kappa=0.366)$ between these two decision-making processes.

Similarly, Cho et al. [9] found fair to moderate reliability when using plain radiographs alone. Notably, because level of experience is expected to improve reliability, they recruited 10 shoulder surgeons with an average of 11.2 years of practice. Using the $\kappa$ correlation 


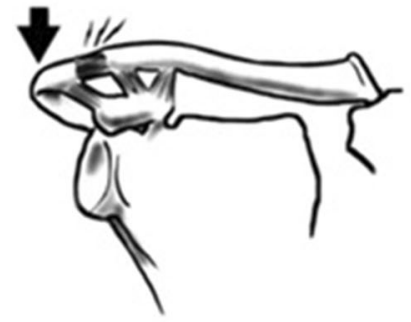

Type 1

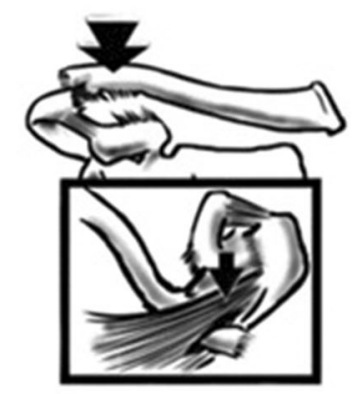

Type IV

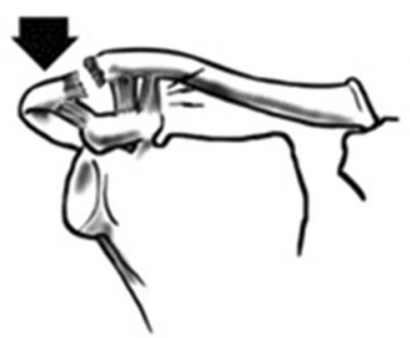

Type II

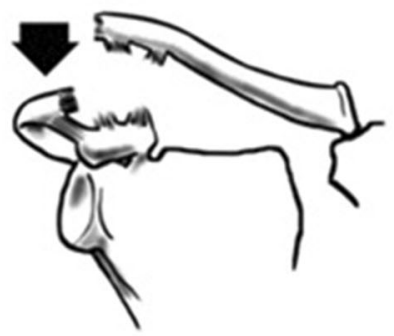

Type V

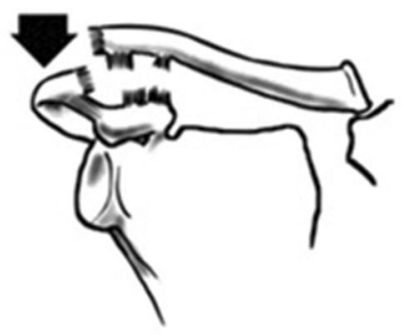

Type III

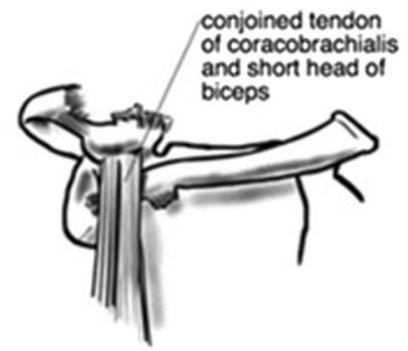

Type VI
Fig. 1 Rockwood's classification of acromioclavicular separations Types I to VI is shown. A Type I injury is a mild sprain of the AC ligament, Type $\mathrm{II}$ is a ruptured $\mathrm{AC}$ ligament and sprained $\mathrm{CC}$ ligaments, Type III is a superior dislocation of the AC joint with ruptured AC ligament, CC ligament, and joint capsule, Type IV is a posterior dislocation of the AC joint with ruptured AC ligament, $\mathrm{CC}$ ligament, and joint capsule, Type $\mathrm{V}$ is a gross superior dislocation of the $\mathrm{AC}$ joint with ruptured $\mathrm{AC}$ ligament, $\mathrm{CC}$ ligament, and joint

coefficient, interobserver and intraobserver reliability of the Rockwood classification was found to be fair $(\kappa=$ $0.214)$ and moderate $(\kappa=0.474)$, respectively [9]. Interobserver and intraobserver reliability of treatment was fair ( $\kappa=0.213$ and 0.399 , respectively) [9].

$\mathrm{Ng}$ et al. [22] assessed reliability among 19 British shoulder surgeons using 24 patients with Zanca-view radiographs alone. Using the weighted $\kappa$ for the Rockwood classification, they found interobserver and intraobserver agreement to be fair $(\kappa=0.253)$ and slight $(\kappa=0.150)$, respectively [22].

Pifer et al. [24] distributed 50 radiographs of AC dislocations to orthopaedic surgeons, musculoskeletal radiologists, and emergency medicine physicians. Using the multirater $\kappa$ statistic, they found moderate classification agreement among orthopaedic surgeons $(\kappa=0.515)$; however, agreement was much lower for musculoskeletal radiologists $(\kappa=0.363)$ and emergency medicine physicians $(\kappa=0.189)$ [24]. Experience appeared to make minimal difference; agreement was only slightly higher among attending orthopaedic surgeons $(\kappa=0.516)$ than orthopaedic residents $(\kappa=0.492)$ [24]. capsule, and Type VI is an inferior dislocation of the $\mathrm{AC}$ joint with rupture of the AC ligament, $\mathrm{CC}$ ligament, and joint capsule. (Reprinted with permission from Lasanianos NG, Panteli M. Acromioclavicular (AC) joint dislocation. In: Lasanianos NG, Kanakaris NK, Giannoudis PV, eds. Trauma and Orthopaedic Classifications. London, UK: Springer-Verlag London; 2015:3-6.)

\section{Computed Tomography}

Attempts have been made using other imaging modalities to further define Rockwood's classification system, but there has yet to be evidence that $\mathrm{CT}$ improves reliability. Cho et al. [9] investigated the effect on reliability of classification and treatment choice when radiographs are viewed with the addition of three-dimensional (3-D) CT. Regarding classification, the combination of 3-D CT and plain films yielded poor interobserver $(\kappa=0.177)$ and moderate intraobserver reliability $(\kappa=0.474)$. Regarding the decision for treatment, interobserver and intraobserver reliability were fair $(\kappa=0.253)$ and moderate $(\kappa=0.554)$, respectively [9].

\section{Ultrasound}

Heers and Hedtmann [12] assessed whether ultrasound could be useful in evaluation of high-grade AC separations when examining the condition of the deltoid and trapezoid muscles. When they compared sonographic and 
intraoperative findings of patients classified as having Types III to V injuries, they found good sensitivity ( $80 \%$ ) and excellent specificity (100\%) for detecting disruption of the deltoid and trapezius muscles and excellent specificity and sensitivity $(100 \%)$ for detecting disruption of their common fascia.

\section{Magnetic Resonance Imaging}

Owing to diagnostic variability among surgeons, several authors have proposed use of MRI to better evaluate adjacent soft tissues. Alyas et al. [2] proposed that a coronal oblique plane MRI parallel to the CC ligament allows adequate observation of the acromioclavicular ligaments and accessory structures, which may be especially useful in excluding higher-grade injuries and identifying additional disease if surgery is considered. Other authors have suggested that the use of MRI to evaluate the coracoclavicular ligament may aid in discerning Type III from Type II and in the decision to operate $[3,29]$.

\section{Limitations}

Limitations to Rockwood's classification system include moderate to poor interobserver and intraobserver reliability. The unsatisfactory ability of a standard AP Zanca view to discern soft tissue injury may be responsible for limited reliability, primarily in cases of low-grade AC separations (Types I, II, and sometimes III) in which clear radiographic measurement criteria are not present. Advanced imaging modalities, such as MRI, that clarify the status of the AC and CC ligaments are not typically used in evaluation of AC separations [22]. In addition, an axial view is obtained only by a minority of orthopaedic surgeons [22], and Type IV AC separations, described as posterior displacement of the distal clavicle in relation to the acromion, may be missed without this view.

A successful radiographic classification can help surgeons determine whether surgical intervention is appropriate. Controversy regarding the surgical indications for AC joint separations was present long before Rockwood's classification [25, 26, 33]. When Rockwood expanded the three-part classifications of Allman [1] and Tossy et al. [32], it was accepted among surgeons that Types I and II were treated nonoperatively, that Types IV, $\mathrm{V}$, and VI might best be treated by surgery, and that management of Type III injuries was controversial. This consensus holds today $[4,5,13,18,21,28,31]$, and the controversy regarding treatment of Type III persists. Historically, studies have shown good clinical results with nonoperative treatment of Type III injuries $[4,7,17,23,30]$, whereas others have shown greater success with surgical treatment $[11,14]$. Lack of agreement may be partly attributable to the lack of clinical examination in such a radiographic classification. Clinical examination of the affected shoulder often can suggest the need for operative intervention, such as the inability to reduce the distal clavicle suggesting buttonholing through the deltotrapezial fascia.

Various surgical techniques, anatomic and nonanatomic, and recommendations regarding timing of surgical intervention have been described, but no consensus on optimal treatment exists [5, 13]. Treatment for Type III injuries also must be individualized based on factors like the patient's activity level, functional impairment, occupational demands, type of sport, level of play, and the patient's aesthetic preferences regarding the injured shoulder.

\section{Conclusions}

The Rockwood classification of AC joint separations uses plain radiographs to describe varying degrees of soft tissue involvement and joint displacement. Rockwood expanded on previous classification systems of AC joint separations to provide a more-detailed description based on pathoanatomy of the injury. Reproducibility and interobserver reliability of the classification is only moderate and is likely limited by the inability of a classification based on plain radiographs to fully assess a soft tissue injury.

\section{References}

1. Allman FL Jr. Fractures and ligamentous injuries of the clavicle and its articulation. J Bone Joint Surg Am. 1967;49:774-784.

2. Alyas F, Curtis M, Speed C, Saifuddin A, Connell D. MR imaging appearances of acromioclavicular joint dislocation. Radiographics. 2008;28:463-479; quiz 619.

3. Antonio GE, Cho JH, Chung CB, Trudell DJ, Resnick D. Pictorial essay: MR imaging appearance and classification of acromioclavicular joint injury. AJR Am J Roentgenol. 2003;180:11031110.

4. Bannister GC, Wallace WA, Stableforth PG, Hutson MA. The management of acute acromioclavicular dislocation: a randomised prospective controlled trial. J Bone Joint Surg Br. 1989;71:848-850.

5. Beitzel K, Cote MP, Apostolakos J, Solovyova O, Judson CH, Ziegler CG, Edgar CM, Imhoff AB, Arciero RA, Mazzocca AD. Current concepts in the treatment of acromioclavicular joint dislocations. Arthroscopy. 2013;29:387-397.

6. Cadenat $F$. The treatment of dislocations and fractures of the outer end of the clavicle. Int Clin. 1917;1:145-169.

7. Calvo E, Lopez-Franco M, Arribas IM. Clinical and radiologic outcomes of surgical and conservative treatment of type III acromioclavicular joint injury. $J$ Shoulder Elbow Surg. 2006;15:300-305. 
8. Chillemi C, Franceschini V, Dei Giudici L, Alibardi A, Salate Santone F, Ramos Alday LJ, Osimani M. Epidemiology of isolated acromioclavicular joint dislocation. Emerg Med Int. 2013;2013:171609.

9. Cho CH, Hwang I, Seo JS, Choi CH, Ko SH, Park HB, Dan J. Reliability of the classification and treatment of dislocations of the acromioclavicular joint. J Shoulder Elbow Surg. 2014;23: 665-670.

10. Flik K, Lyman S, Marx RG. American collegiate men's ice hockey: an analysis of injuries. Am J Sports Med. 2005;33:183187.

11. Gstettner C, Tauber M, Hitzl W, Resch H. Rockwood type III acromioclavicular dislocation: surgical versus conservative treatment. J Shoulder Elbow Surg. 2008;17:220-225.

12. Heers G, Hedtmann A. Correlation of ultrasonographic findings to Tossy's and Rockwood's classification of acromioclavicular joint injuries. Ultrasound Med Biol. 2005;31:725-732.

13. Johansen JA, Grutter PW, McFarland EG, Petersen SA. Acromioclavicular joint injuries: indications for treatment and treatment options. J Shoulder Elbow Surg. 2011;20(2 suppl):S7082.

14. Joukainen A, Kröger H, Niemitukia L, Mäkelä EA, Väätäinen U. Results of operative and nonoperative treatment of Rockwood types III and V acromioclavicular joint dislocation: a prospective, randomized trial with an 18- to 20-year follow-up. Orthop $J$ Sports Med. 2014;2:2325967114560130. doi:10.1177/232596711 4560130.

15. Kaplan LD, Flanigan DC, Norwig J, Jost P, Bradley J. Prevalence and variance of shoulder injuries in elite collegiate football players. Am J Sports Med. 2005;33:1142-1146.

16. Kraeutler MJ, Williams GR Jr, Cohen SB, Ciccotti MG, Tucker BS, Dines JS, Altchek DW, Dodson CC. Inter- and intraobserver reliability of the radiographic diagnosis and treatment of acromioclavicular joint separations. Orthopedics. 2012;35: e1483-1487.

17. Larsen E, Hede A. Treatment of acute acromioclavicular dislocation: three different methods of treatment prospectively studied. Acta Orthop Belg. 1987;53:480-484.

18. Lemos MJ. The evaluation and treatment of the injured acromioclavicular joint in athletes. Am J Sports Med. 1998; 26:137-144.

19. Mazzocca AD, Arciero RA, Bicos J. Evaluation and treatment of acromioclavicular joint injuries. Am J Sports Med. 2007;35:316329.
20. McCall D, Safran MR. Injuries about the shoulder in skiing and snowboarding. Br J Sports Med. 2009;43:987-992.

21. Mikek M. Long-term shoulder function after type I and II acromioclavicular joint disruption. Am J Sports Med. 2008; 36:2147-2150

22. Ng CY, Smith EK, Funk L. Reliability of the traditional classification systems for acromioclavicular joint injuries by radiography. Shoulder Elbow. 2012;4:266-269.

23. Phillips AM, Smart C, Groom AF. Acromioclavicular dislocation: conservative or surgical therapy. Clin Orthop Relat Res. 1998;353:10-17.

24. Pifer M, Ashfaq K, Maerz T, Jackson A, Baker K, Anderson K. Intra- and interdisciplinary agreement in the rating of acromioclavicular joint dislocations. Phys Sportsmed. 2013;41:25-32.

25. Post M. Current concepts in the diagnosis and management of acromioclavicular dislocations. Clin Orthop Relat Res. 1985;200: 234-247.

26. Powers JA, Bach PJ. Acromioclavicular separations: closed or open treatment? Clin Orthop Relat Res. 1974;104:213-223.

27. Rios CG, Mazzocca AD. Acromioclavicular joint problems in athletes and new methods of management. Clin Sports Med. 2008;27:763-788.

28. Rockwood CA Jr. Fractures and dislocations of the shoulder. In: Rockwood CA Jr, Green DP, eds. Fractures in Adults. Philadelphia, PA: Lippincott; 1984:860-910.

29. Schaefer FK, Schaefer PJ, Brossmann J, Hilgert RE, Heller M, Jahnke T. Experimental and clinical evaluation of acromioclavicular joint structures with new scan orientations in MRI. Eur Radiol. 2006;16:1488-1493.

30. Schlegel TF, Burks RT, Marcus RL, Dunn HK. A prospective evaluation of untreated acute grade III acromioclavicular separations. Am J Sports Med. 2001;29:699-703.

31. Tamaoki MJ, Belloti JC, Lenza M, Matsumoto MH, Gomes Dos Santos JB, Faloppa F. Surgical versus conservative interventions for treating acromioclavicular dislocation of the shoulder in adults. Cochrane Database Syst Rev. 2010;8:CD007429.

32. Tossy JD, Mead NC, Sigmond HM. Acromioclavicular separations: useful and practical classification for treatment. Clin Orthop Relat Res. 1963;28:111-119.

33. Urist MR. Complete dislocations of the acromiclavicular joint; the nature of the traumatic lesion and effective methods of treatment with an analysis of forty-one cases. J Bone Joint Surg Am. 1946; 28:813-837. 